\title{
Copro-necrophagous beetle (Coleoptera: Scarabaeidae) diversity in an agroecosystem in Yucatan, Mexico
}

\author{
Enrique Reyes Novelo ${ }^{1 *}$, Hugo Delfín-González ${ }^{1 * *} \&$ Miguel Ángel Morón $^{2}$ \\ 1 Universidad Autónoma de Yucatán, Facultad de Medicina Veterinaria y Zootecnia, Apartado Postal 4-116, 97100 \\ Mérida, Yucatan, Mexico; *enovelo@fmvz.uady.mx, **gdelfín@tunku.uady.mx \\ 2 Instituto de Ecología, A.C. Departamento de Entomología, Apartado Postal 63, 91000 Xalapa, Veracruz, Mexico; \\ miguel.moron@ecologia.edu.mx
}

Received 10-X-2005. Corrected 27-VI-2006. Accepted 15-XI-2006.

\begin{abstract}
Scarabaeinae are sensitive to structural habitat changes caused by disturbance. We compared copronecrophagous beetle (Scarabaeinae) community structure in three differently managed zones within an agroecosystem of the northern Yucatan Peninsula, Mexico. We placed dung and carrion traps once a month from June 2004 through May 2005. The beetle community included 17 species from the genera Canthon, Canthidium, Deltochilum, Pseudocanthon, Malagoniella, Onthophagus, Phanaeus, Copris, Uroxys, Sisyphus and Ateuchus. The secondary vegetation had a higher beetle diversity than the other two zones. Species richness was highest in the Brosimum alicastrum plantation. The pasture had the lowest species diversity and richness, but exhibited the highest abundance of Scarabaeinae in the dry season. The two zones with extensive tree cover were the most diverse. Roller beetles were dominant over burrower species and small-sized species outnumbered large species. Our data show two important issues: beetle species in the pasture extended their activity to the beginning of the dry season, while abundances dropped in the other, unirrigated zones; and the possibility that the Scarabaeinae living in neotropical forests are opportunistic saprophages and have specialized habits for resources other than dung. The $B$. alicastrum plantation is beneficial to the entire ranch production system because it functions as a dispersion and development area for stenotopic species limited to tree cover. Rev. Biol. Trop. 55 (1): 83-99. Epub 2007 March. 31.
\end{abstract}

Key Words: Scarabaeinae, fragmentation, Brosimum alicastrum, agroecosystems, biodiversity, Yucatan.

The 1980's saw an increase in concern among the scientific community and general society about the affect of human activities and development on biological diversity because these were seen as the main source of direct and indirect threats to biodiversity (Favila and Halffter 1997). Paradoxically, as biodiversity diminishes, human beings require more diverse biological entities for their well-being, be it for direct, indirect, ethical or esthetic use (Halffter et al. 2001).

The principal acknowledged challenge to diversity is ecosystem fragmentation and reduction from human activities (Gaston 1996). One of the human activities that directly affects biodiversity is cattle ranching, though efforts are now being made to address its effect using silvapastoral systems in livestock production. A number of authors (Nair 1997, Wadsworth 2000, Chacón-León and Harvey 2004, Munroe et al. 2004, among others) have described the multiple economic, ecological and social benefits of these productive systems.

Different studies have shown Scarabaeinae species to be sensitive to structural habitat changes caused by disturbance. In a disturbed habitat, they exhibit drastic permutations in their distribution and development, and they must adapt to the new conditions as these arise (Halffter and Favila 1993, Halffter and Arellano 2002, Arellano and Halffter 2003). 
The present study was aimed to describe and compare copronecrophagous beetle (Scarabaeinae) community structure in three zones managed differently within an agroecosystem located in the northern Yucatan Peninsula. The data were then analyzed to determine the contribution of this silvopastoral system to local-scale diversity, and to establish if a relationship exists between beetle species richness, soil depth and nesting patterns in the study area.

\section{MATERIALS AND METHODS}

Study area: The study was done on Kampepem Ranch, a cattle ranch with an area of 50 ha. It is located near the Cuxtal Nature Reserve at $20^{\circ} 50^{\prime} 14^{\prime \prime} \mathrm{N}$ and $89^{\circ} 39^{\prime} 17^{\prime \prime} \mathrm{W}$, in San José Tzal, municipality of Mérida, Yucatan, Mexico. Study area altitude is approximately $15 \mathrm{~m}$ asl. Climate in the region is drier than the hot subhumids $\left(\mathrm{AW}_{0}\left(\mathrm{i}^{\prime}\right) \mathrm{g}\right)$, with annual rainfall ranging from 800 to 1000 $\mathrm{mm}$ which occurs mainly during the rainy season between May and October (Anonymous, 1995). The original vegetation is tropical deciduous forest (Flores and Espejel 1994).

Samples were collected in three zones within the ranch: pastures; a Brosimum alicastrum plantation; and secondary vegetation. None of the three study zones is or has been treated with inorganic fertilizer or herbicides.

Of the total area of the ranch, $110000 \mathrm{~m}^{2}$ are used for grass production (Cynodon plectostachyus and Brachiaria brizantha). The grass pastures are directly grazed by 80 animals (ovines) twice a day. Water cannons are used to irrigate one to three times every ten days, depending on the season. Fourteen years ago the soils were mechanically moved and soil was added from external soil banks. Thus, soils in this zone are $52 \mathrm{~cm}$ deep and have from two to five percent stoniness, with no rocks and are red.

The ranch has a plantation of Brosimum alicastrum Swartz (Moraceae) (common name = ramon) covering approximately $40000 \mathrm{~m}^{2}$.
These trees are older than eight years, range from three to six meters in height, and are managed using variable trimming year round to provide feed for ovine livestock. The area is manually cleared of weeds and the trees are irrigated with microspray. Soils in this area are $21 \mathrm{~cm}$ deep, dark-colored rendzic Leptosols (LPrz) with $40 \%$ stoniness and $60 \%$ rockiness.

The secondary vegetation on the ranch has remained uncut for more than 40 years and covers about $53500 \mathrm{~m}^{2}$. It is dominated by Gymnopodium floribundum Rolfe (Polygonaceae) and contains different vegetal strata, with some trees reaching eight meters height. Plant species in this area include Caesalpinia gaumeri Greenm., Piscidia piscipula (L.) Sarg., Mimosa bahamensis Benth., Havardia albicans (Kunth.) Benth., Acacia gaumeri Blake (Fabaceae), Randia longiloba Hamsley (Rubiaceae), Ceiba schottii Britton \& Baker (Bombacaceae), Bursera simaruba (L.) Sarg. (Burceraceae), Helicteres baruensis Jacq. (Sterculiaceae), Diospyros cuneata Standley (Ebenaceae) and Thouinia paucidentata Radlk (Sapindaceae). Soils are chromic Cambisols (CMcr), $38 \mathrm{~cm}$ deep, with red color, 80\% stoniness and $20 \%$ rockiness.

Scarabaeinae collection: Five conventional dung traps (or coprotraps) and five carrion traps (or necrotraps) were placed along two transects (250 m-long), in each of the three sampled zones. Distance between traps was 50 $\mathrm{m}$ and that between transects was $10 \mathrm{~m}$. The traps were placed for 24 hours once a month during the one-year study period (June 2004 to May 2005). Coprotraps were baited with fresh human dung and necrotraps with shrimp that had decomposed for five days. Collected specimens were deposited in the regional entomology collection of the Autonomous University of Yucatan (Universidad Autónoma de Yucatán, CER-UADY) and some duplicates were placed in the entomology collection of the Institute of Ecology, Xalapa, Ver. (Instituto de Ecología, IEXA).

Data analysis: Scarabaeinae community structure was analyzed using the criteria of 
Halffter and Favila (1993) and Favila and Halffter (1997): segregation by feeding habits (strict coprophages, strict necrophages and generalists); food relocation (percentage of burrowers and rollers); spatial segregation (percentage of umbrophiles and heliophiles); temporal segregation (percentage diurnal and nocturnal); and size segregation (small -3 to 8 $\mathrm{mm}$, medium -9 to $14 \mathrm{~mm}$, large $-15+\mathrm{mm}$ ). Nesting patterns were determined according to Halffter and Edmonds (1982).

Species accumulation curves were built, the data randomized 100 times and the Exponential Model and Clench Equation applied (Soberón and Llorente 1993, Moreno 2001). Dominancediversity curves were generated to analyze relative abundance and the distribution of the different species in the different zones (Favila and Halffter 1997).

The Hill number series was calculated to determine dominance, as were Hill's evenness index and the Shannon-Wiener Index for heterogeneity. The Hutcheson t test (Magurran 1988, Moreno 2001) was applied to identify possible differences between heterogeneity at the sites. Index calculations were done with the EstimateS 7.0 (Colwell 2004), SpAcc2
Beta version (Anonymous, 2003) and BIODIV (Beav and Penev 1995) programs.

\section{RESULTS}

Species richness and abundance: Specimen collection produced 5807 individuals from 17 species and 11 Scarabaeinae genera. A total of 1826 specimens from 16 species were collected in the ramon plantation, 2171 from 11 species in the pasture and 1810 from 14 species in the secondary vegetation (Table 1).

Species accumulation per sample area: For the ramon plantation the Clench model produced an estimate of 21 species $(a=0.449282$ and $b=0.022464)$ and the exponential model produced 17 species $(a=0.516676$ and $b=$ 0.030401 ), both extrapolated from 300 samples (Fig. 1-A). According to the Clench model this area contained $76 \%$ of the area's probable richness and the exponential model showed it to be $94 \%$.

The Clench model curves for the pasture gave an estimate of 13 species $(a=0.779575$

TABLE 1

Specific richness and abundance of Scarabaeinae collected at Kampepem Ranch between June 2004 and May 2005

Species

Canthon (Canthon) indigaceus chevrolati Harold, 1868

Canthon (Canthon) cyanellus cyanellus LeConte, 1859

Canthon (Glaphyrocanthon) leechi (Martínez, Halffter y Halffter, 1964) Canthon (Glaphyrocanthon) euryscelis Bates, 1887

Pseudocanthon perplexus (LeConte, 1847)

Canthidium sp.

Malagoniella astyanax yucateca (Harold, 1863)

Deltochilum (Hybomidium) gibbosum sublaeve Bates, 1887

Deltochilum (Deltochilum) scabriusculum scabriusculum Bates, 1887

Deltochilum (Hybomidium) lobipes Bates, 1887

Onthophagus landolti Harold, 1880

Onthophagus batesi Howden y Cartwright, 1963

Phanaeus wagneri Harold 1863

Copris lugubris Boheman, 1858

Uroxys nov. sp.

Ateuchus perezvelai Kohlmann, 2000

Sisyphus mexicanus Harold, 1863

Totals

$\mathrm{C}=$ coprotraps, $\mathrm{N}=$ necrotraps

\begin{tabular}{ccccccccc}
\multicolumn{4}{c}{ Ramon } & \multicolumn{3}{c}{ Pasture } & \multicolumn{3}{c}{ Secveg } \\
$\mathrm{C}$ & $\mathrm{N}$ & Total & $\mathrm{C}$ & $\mathrm{N}$ & Total & $\mathrm{C}$ & $\mathrm{N}$ & Total \\
283 & 24 & 307 & 293 & 20 & 313 & 6 & 0 & 6 \\
3 & 17 & 20 & 1 & 2 & 3 & 28 & 101 & 129 \\
390 & 95 & 485 & 584 & 108 & 692 & 536 & 151 & 687 \\
1 & 0 & 1 & 0 & 0 & 0 & 65 & 10 & 75 \\
32 & 21 & 53 & 81 & 5 & 86 & 0 & 0 & 0 \\
179 & 24 & 203 & 402 & 61 & 463 & 49 & 16 & 65 \\
2 & 0 & 2 & 3 & 1 & 4 & 1 & 0 & 1 \\
0 & 2 & 2 & 0 & 0 & 0 & 9 & 11 & 20 \\
1 & 0 & 1 & 1 & 0 & 1 & 3 & 1 & 4 \\
2 & 2 & 4 & 0 & 2 & 2 & 3 & 0 & 3 \\
654 & 65 & 719 & 577 & 27 & 604 & 326 & 41 & 367 \\
2 & 0 & 2 & 0 & 0 & 0 & 0 & 0 & 0 \\
3 & 0 & 3 & 0 & 0 & 0 & 5 & 0 & 5 \\
1 & 0 & 1 & 2 & 0 & 2 & 4 & 0 & 4 \\
19 & 3 & 22 & 1 & 0 & 1 & 369 & 54 & 423 \\
0 & 0 & 0 & 0 & 0 & 0 & 15 & 6 & 21 \\
1 & 0 & 1 & 0 & 0 & 0 & 0 & 0 & 0 \\
$1 \mathbf{5 7 3}$ & $\mathbf{2 5 3}$ & $\mathbf{1 8 2 6}$ & $\mathbf{1 9 4 5}$ & $\mathbf{2 2 6}$ & $\mathbf{2 1 7 1}$ & $\mathbf{1 4 1 9}$ & $\mathbf{3 9 1}$ & $\mathbf{1 8 1 0}$
\end{tabular}



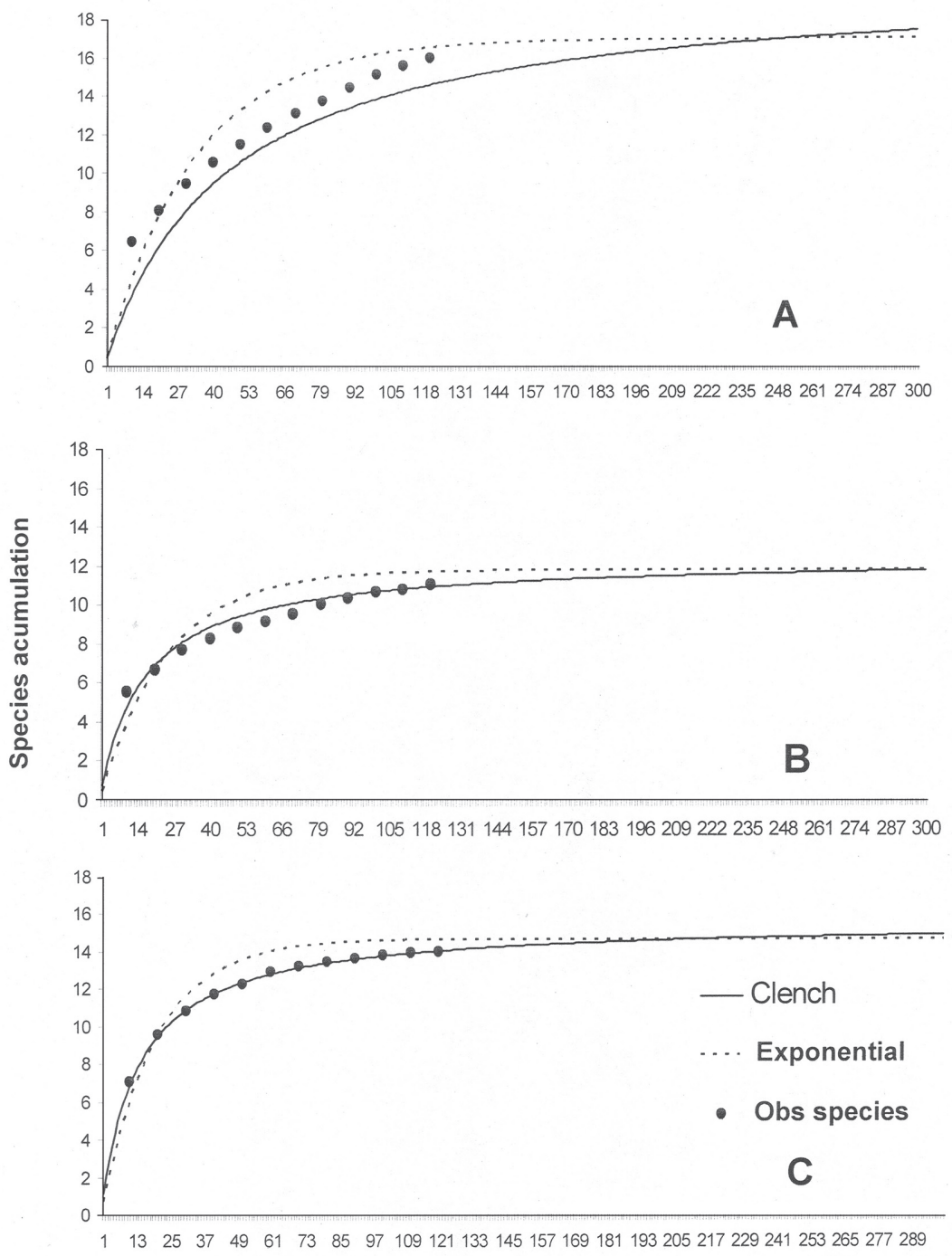

No. of Traps

Fig. 1. Species accumulation curves according to the Clench and exponential models for each zone in Kampepem Ranch. $\mathrm{A}=$ ramon, $\mathrm{B}=$ pasture, $\mathrm{C}=$ secondary vegetation, Obs species $=$ Observed species.

and $b=0.063071)$ and the exponential model one of $12(a=0.484208$ and $b=0.041057)$. Richness was estimated as $85 \%$ by the Clench and $92 \%$ by the exponential model (Fig. 1-B).

In the secondary vegetation the Clench model estimated 16 species $(\mathrm{a}=1.207445$ and $b=0.077676)$ and the exponential model 15 species $(a=0.76682$ and $b=0.05225)$, that is, $87.5 \%$ (Clench) and $93 \%$ (exponential) of probable richness (Fig. 1-C).

Dominance: Dominance was accounted for by four species in each of the three zones (Table 2), though the dominant species profile was slightly different in the secondary vegetation (Fig. 2). Dominant species in the ramon plantation were Onthophagus landolti(39.37\%), 
TABLE 2

Diversity index values calculated from species abundances in each zone of Kampepem Ranch

Abundances

Number of species (N0)

Common species (N1)

Dominant species (N2)

Rare species [NO - (N1+N2)]

Shannon-Wiener index

Eveness (N1/N2)

$\begin{array}{ccc}\text { Ramon } & \text { Pasture } & \text { Secveg } \\ 1826 & 2171 & 1810 \\ 16 & 11 & 14 \\ 4.62 & 4.47 & 5.2 \\ 3.74 & 4.05 & 4.03 \\ 7.64 & 2.48 & 4.77 \\ 1.53 & 1.5 & 1.65 \\ 0.809 & 0.906 & 0.775\end{array}$

Canthon leechi (26.56\%), Canthon indigaceus (16.81\%) and Canthidium sp (11.11\%) (Fig. $2)$. In the pasture they were $C$. leechi $(31.87 \%)$, O. landolti (27.82\%), Canthidium sp. (21.32\%) and $C$. indigaceus $(14.41 \%)$. In the secondary vegetation they were $C$. leechi $(37.95 \%)$, Uroxys sp. nov. (23.37\%), O. landolti $(20.27 \%)$ and C. cyanellus (7.12\%) (Fig. 2).

Diversity: The secondary vegetation community had the highest diversity. Four common species were identified in the pasture and five each in the other two zones. The highest number of rare species (eight) was found in the ramon plantation, and the lowest (two) in the pasture (Table 2).

Rare species in the $B$. alicastrum plantation included Sisyphus mexicanus, Copris lugubris, Deltochilum scabriusculum and Canthon euryscelis $(0.05 \%$ abundance each); Onthophagus batesi, D. gibbosum and Malagoniella astyanax $(0.10 \%$ abundance each); and Phanaeus wagneri $(0.16 \%)$. The rare species in the pasture were Uroxys sp. nov. $(0.04 \%)$, and $D$. scabriusculum $(0.04 \%)$, while the secondary vegetation had $M$. astyanax $(0.05 \%), D$. lobipes $(0.16 \%)$, C. lugubris $(0.22 \%)$, D. scabriusculum $(0.22 \%)$ and P. wagneri $(0.27 \%)$.

Some of the species were rare in all the study areas while others were abundant at some sites and rare in others. For example, Uroxys sp. nov. was dominant in the secondary

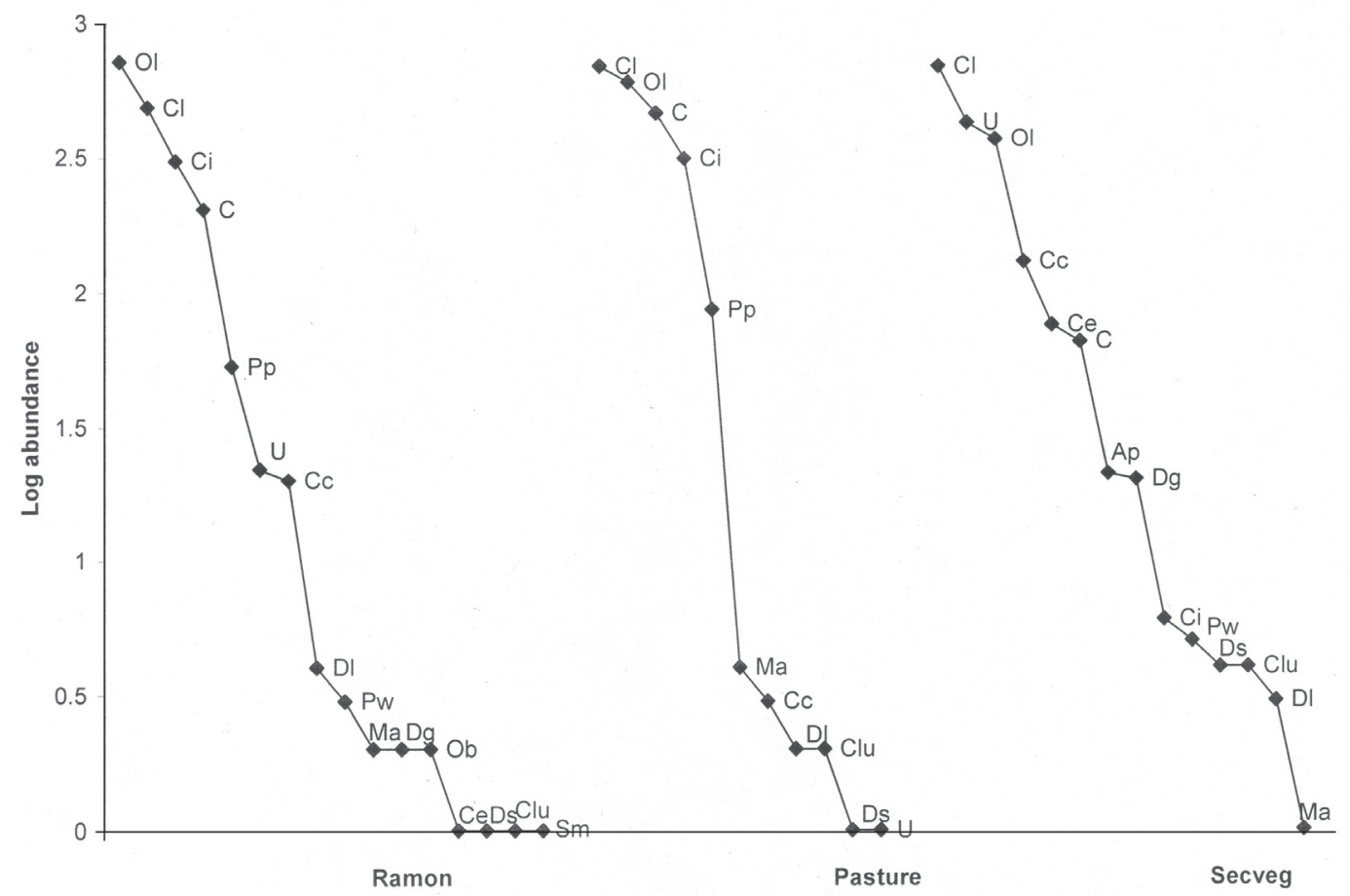

Fig. 2. Dominance-diversity curves for each sampled zone. $\mathrm{Ol}=$ Onthophagus landolti, $\mathrm{Cl}=$ Canthon leechi, $\mathrm{Ci}=$ Canthon indigaceus, $\mathrm{C}=$ Canthidium $\mathrm{sp}, \mathrm{Pp}=$ Pseudocanthon perplexus, $\mathrm{U}=$ Uroxys sp. nov., $\mathrm{Cc}=$ Canthon cyanellus, $\mathrm{Dl}=$ Deltochilum lobipes, $\mathrm{Pw}=$ Phanaeus wagneri, $\mathrm{Ma}=$ Malagoniella astyanax, $\mathrm{Dg}=$ Deltochilum gibbosum, $\mathrm{Ob}=$ Onthophagus batesi, $\mathrm{Ce}=$ Canthon euryscelis, $\mathrm{Ds}=$ Deltochilum scabriusculum, $\mathrm{Clu}=$ Copris lugubris, $\mathrm{Sm}=$ Sisyphus mexicanus, Ap = Ateuchus perezvelai, Secveg = Secondary vegetation. 
vegetation, common in the ramon plantation and rare in the pasture. Community evenness was highest in the pasture and lowest in the secondary vegetation (Table 2 ).

The Shannon-Wiener value for the secondary vegetation was significantly different from those of the ramon plantation and the pasture (secveg vs. pasture: $\mathrm{T}_{c}=5.88>\mathrm{T}_{t}=1.645, \mathrm{gl}=$ 805; secveg vs. ramon: $\mathrm{T}_{c}=3.87>\mathrm{T}_{t}=1.645$, $\mathrm{gl}=3180 ; \alpha=0.05)$, and no difference existed between the latter two zones $\left(\mathrm{T}_{c}=1.37<\mathrm{T}_{t}=\right.$ $1.645, \mathrm{gl}=1020 ; \alpha=0.05)$.

Seasonality: Scarabaeinae abundance exhibited a clear peak between June and October, during the rainy season (Fig. 3). Abundance decreased in the following months to a low from January to March, during the dry season. Abundance also exhibited bimonthly peaks during the one-year study period, with each new generation of beetles (Fig. 4). At least three significant peaks were recorded in each zone, with a noteworthy peak in the pasture at the beginning of the dry season, probably resulting from the artificially moist conditions created by irrigation.

Seasonality varied slightly between the two most abundant areas. In the ramon plantation there were two generations of $O$. landolti, one of $C$. leechi and one of $C$. indigaceus (Fig. 4-A). By contrast, in the secondary vegetation there were three generational peaks for $O$. landolti during the rainy season and one during the dry season, two peaks for $C$. leechi during the rainy season and one for $C$. cyanellus, also in the rainy season. Uroxys sp. nov. had two generational peaks, one at the beginning and another at the end of the dry season (Fig. 4-B).

The generational peaks for beetle species in the pasture differed from those in the ramon plantation and secondary vegetation. For example, $O$. landolti had four generations during the year, as occurred in the secondary vegetation, but with higher dry season abundances. The pasture also had three C. leechi abundance peaks, one more than in the other zones, with one at the beginning of the dry season. Canthidium sp. had one generation during

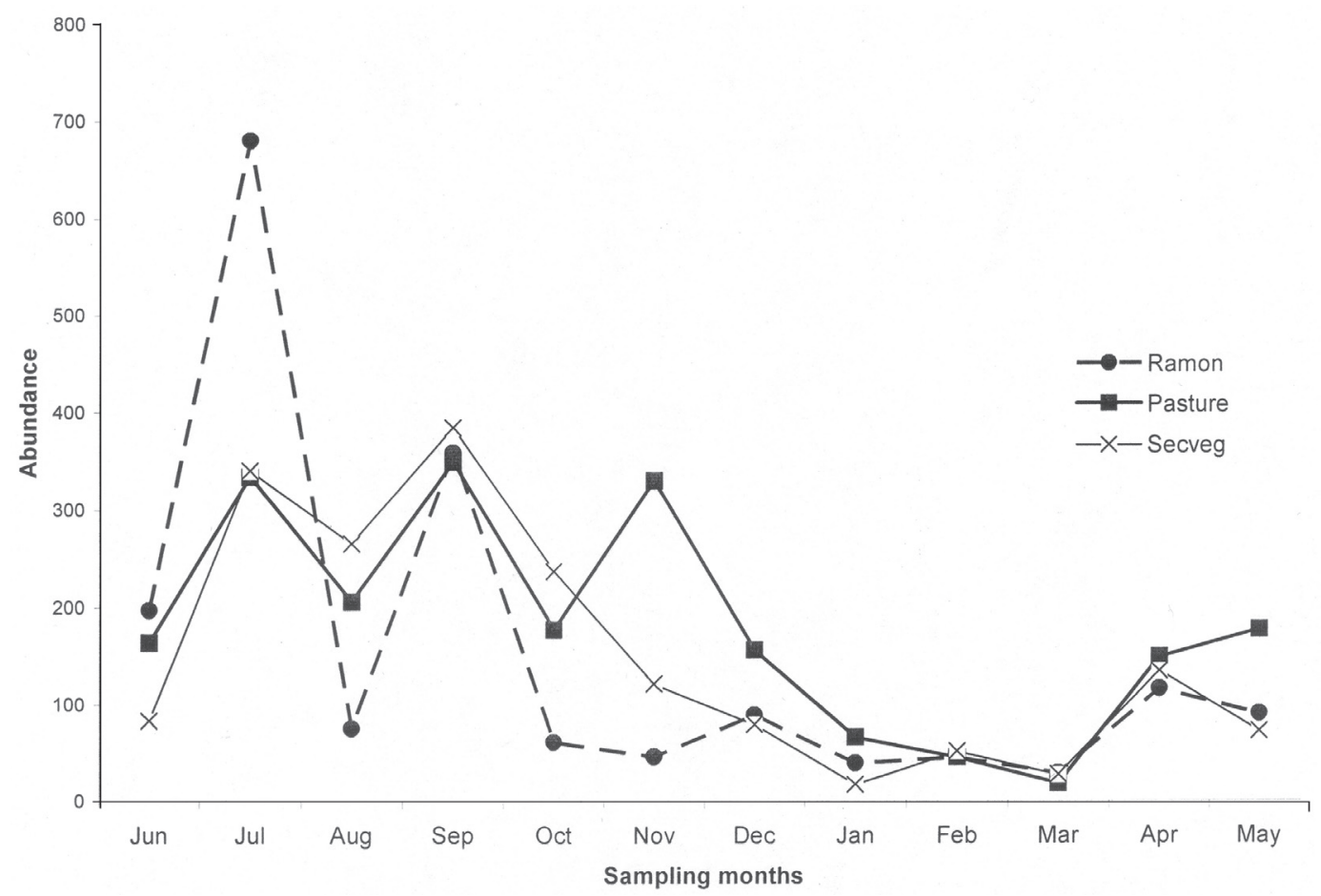

Fig. 3. Scarabaeinae abundance in different areas. Ramon $=$ Ramon Plantation, Secveg $=$ Secondary vegetation. 

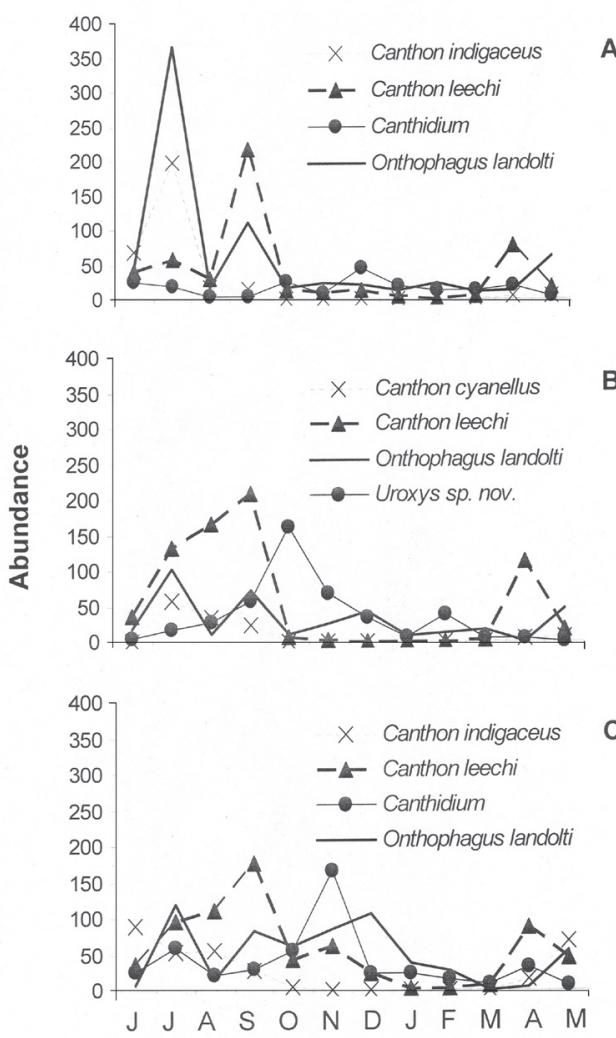

Fig. 4. Fluctuation of the four most abundant species per zones during one-year study period: $\mathrm{A}=$ Ramon, $\mathrm{B}=$ secondary vegetation, $\mathrm{C}=$ pasture.

the rainy season and another at the beginning of the dry season (Fig. 4-C).

Spatial segregation: Both the ramon plantation and the secondary vegetation had a higher percentage of species associated with shade environments (umbrophile) than with open, sunny areas (heliophile). The secondary vegetation had the highest percentage of shade species. In contrast, the pasture had a higher percentage of species associated with open, sunny environments (Fig. 5-A). The heliophile species in the pasture were the same as those in the other areas, but umbrophile species richness was very low in this zone (Tables 2 and 3 ).
Feeding segregation: Most of the collected species were coprophagous, with a lower percentage of necrophagous and generalist species (Fig. 5-B). The coprophages dominated in all three zones, though the pasture had the lowest percentage of necrophages and generalists. The generalists were best represented in the secondary vegetation, and there was little necrophage presence in all three zones.

Food relocation: Roller species dominated burrower species in all three zones (Fig. 5-C). Burrowers were most abundant in the secondary vegetation, and were almost all small in size in all three zones, though one large- $(P$. wagneri) and one medium-sized (C. lugubris) burrower species were identified.

Temporal segregation: There was a larger percentage of nocturnal species in all three zones, though the lowest diurnal species percentage was in the pasture (Fig. 5-D). Diurnal species recorded in the two arboreal zones included $C$. euryscelis, $P$. wagneri and S. mexicanus.

Size segregation: Small-sized species were more abundant (by percentage) than medium- and large-sized species (Fig. 5-E). Only two medium-sized species $(C$. indigaceus and Copris lugubris) and five large-sized species (D. gibbosum, D. lobipes, D. scabriusculum, $M$. astyanax and $P$. wagneri) were collected. The remaining ten recorded species were small (Table 3 ).

Nesting patterns: Accounting for over $50 \%$ of the beetle species in all three zones, the type IV nesting pattern (roller) species was clearly dominant, followed by type I (simplenest, burrower) species (Fig. 6). The pasture had no type II pattern (complex nest, large burrower) species because no Phanaeus sp. were collected there. Type V pattern (roller) species were represented by a single species $(C$. cyanellus) in all three zones. 


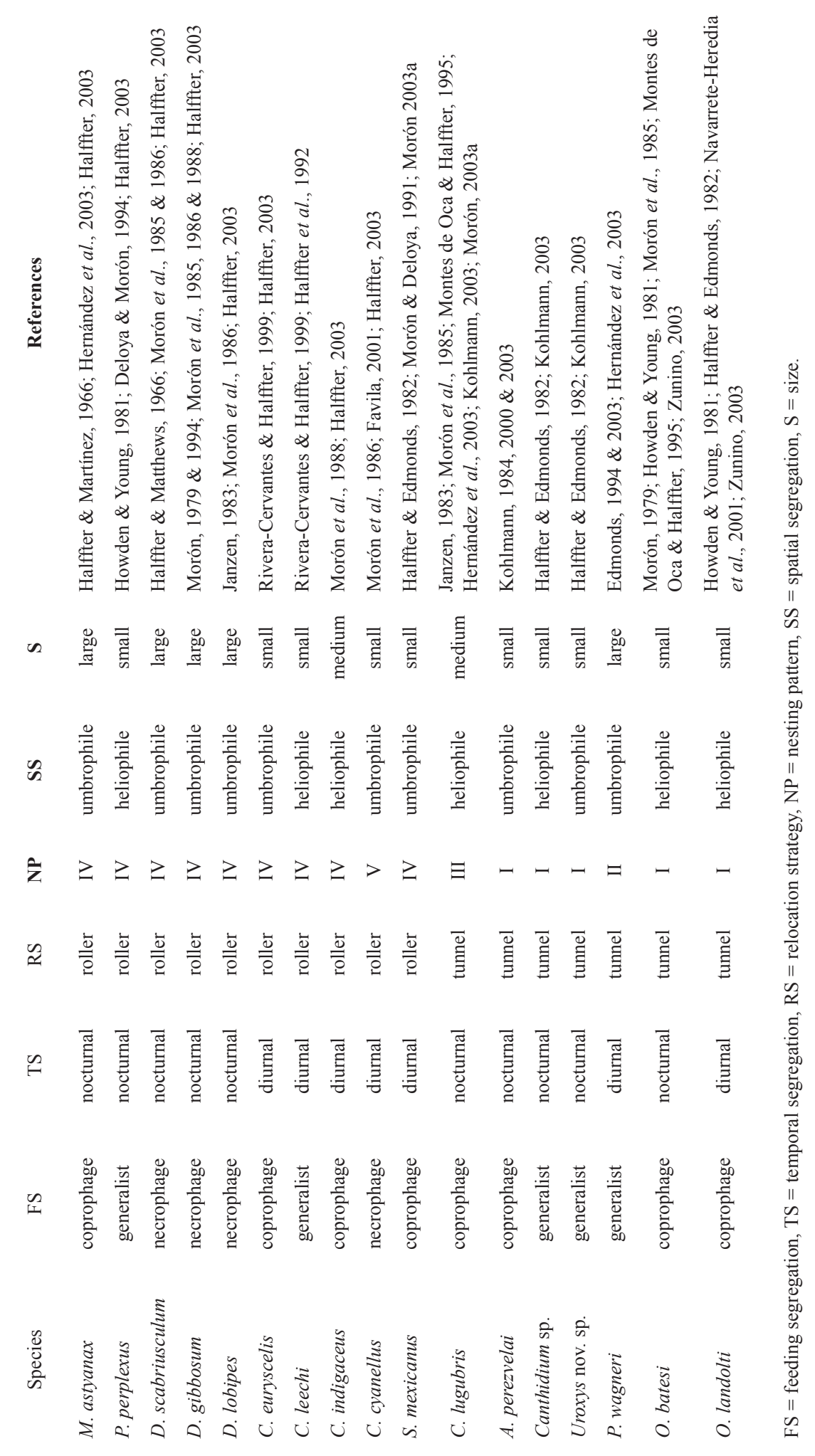




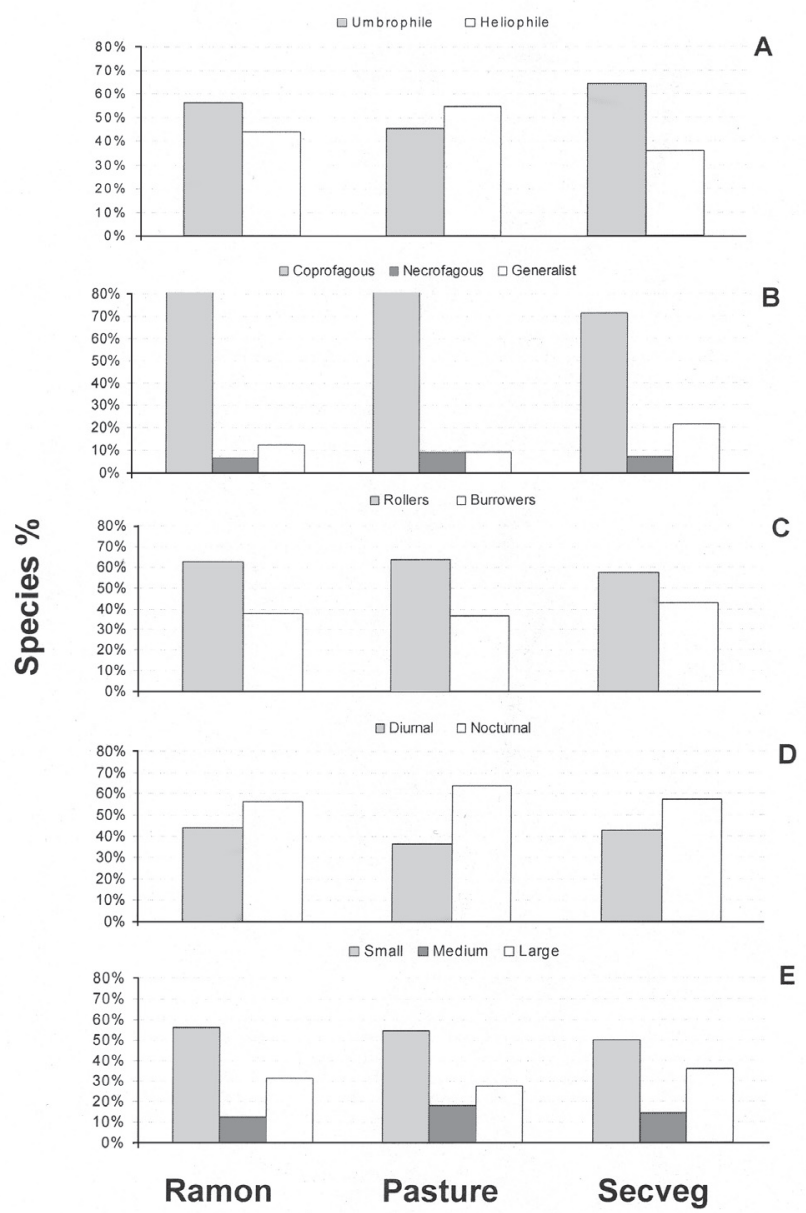

Fig. 5. Scarabaeinae community structure: $\mathrm{A}=$ Spatial segregation, $\mathrm{B}=$ Feeding segregation, $\mathrm{C}=$ Feed relocation, $\mathrm{D}=$ Temporal segregation, $\mathrm{E}=$ Size segregation; Ramon $=$ Ramon Plantation, Secveg $=$ Secondary vegetation.

\section{DISCUSSION}

The state of Yucatan is known within Mexico as having the most deforested and broadly disturbed original vegetation coverage, with from 65 to $70 \%$ of its surface currently in secondary vegetation. In recent history, this impact has largely been due to urban growth, agriculture, and cattle ranching, though vegetal cover was also modified by the ancient Mayan civilization and by henequen (Agave fourcroides) cultivation (Anonymous, 2002, Vester and Calmé 2003).

This loss and fragmentation of vegetal cover goes well beyond the state of Yucatan.
It is a worldwide problem that leads to loss of and changes in biodiversity. In response, many organizations and countries have begun promoting conservation of biological diversity and sustainable, planned of use of natural resources (Carabias 2003). Special attention has been given to development of agroforest production systems. These are potentially adaptable to the Yucatan Peninsula because there is a history of traditional production systems in the region that fit within this definition and that coexist well with modern technologies (JiménezOsornio et al. 2003). Agroforest systems have been shown to positively effect diversity in the areas where they are established (Estrada et al. 


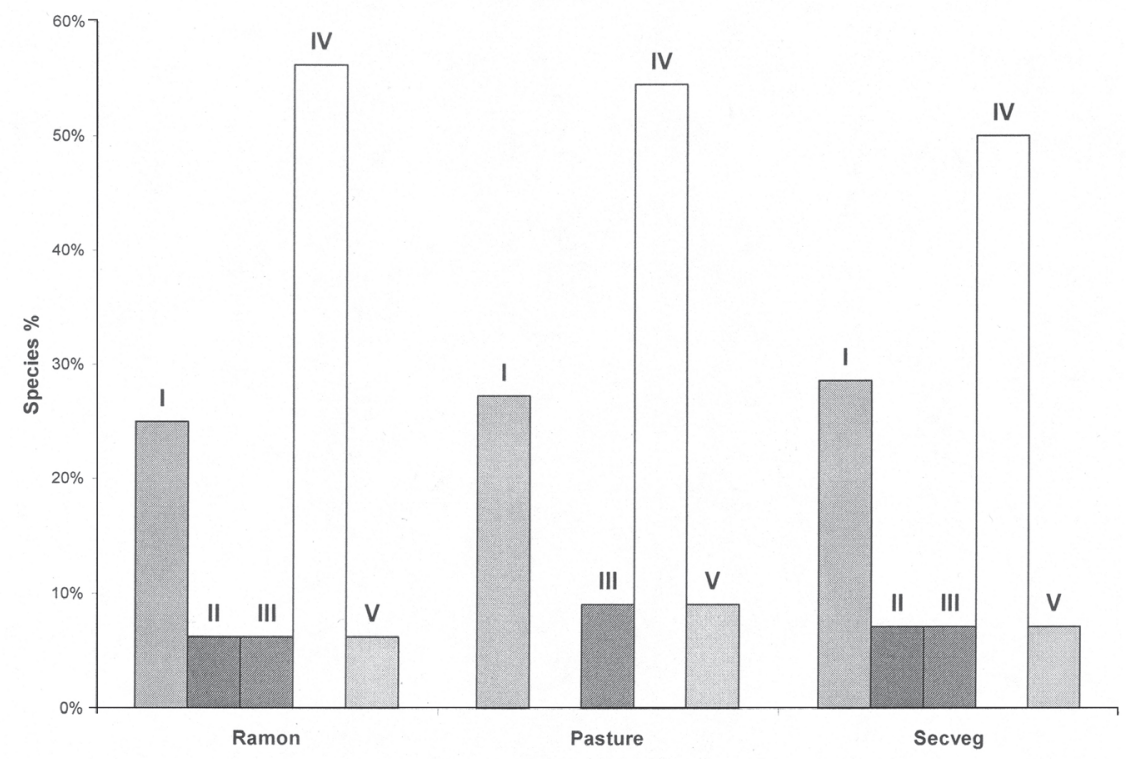

Fig. 6. Scarabaeinae nesting patterns. Ramon $=$ Ramon Plantation, Secveg $=$ Secondary vegetation.

1998, Hernández et al. 2003), which agrees with the present results.

The beetle species richness reported here for northern Yucatan includes a new fauna inventory for neotropical Scarabaeinae. In Morón's (2003a) compendium, fifteen species are reported as known in this location, while in a preliminary faunistic study, Peraza-Flores (2004) mentions that only twelve of the 31 Scarabaeinae species known in Yucatan are found in the state's northern region. The present report includes five new records for this region: $P$. wagneri, $C$. euryscelis, $O$. batesi, $S$. mexicanus and $C$. lugubris.

The species accumulation model results indicate that the sampling effort was adequate since from 80 to $90 \%$ of estimated richness was collected in the samples. This is an acceptable percentage according to Moreno and Halffter (2000).

Our results for species richness per zone and the diversity indices coincide with those of other authors (Peck and Forsyth 1982, Halffter 1991, Halffter et al. 1992, Spector and Forsyth 1998, Spector and Ayzama 2003). They also show the close association between the Scarabaeinae and vegetal cover since the zones with greater tree cover had higher beetle species diversity.

The secondary vegetation had the highest Scarabaeinae diversity, though the ramon plantation had a higher species richness. This discrepancy resulted from the coincidence of the umbrophile and heliophile species in the ramon plantation. This zone has a different arboreal structure than the secondary vegetation zone because the trees are planted in rows, and the spaces between the rows are manually weeded, creating spaces where light enters. In contrast, the secondary vegetation has a tighter structure and different strata. This produced results like $P$. perplexus, a beetle found in open disturbed areas (Howden and Young 1981, Deloya and Morón 1994), being collected in the ramon plantation but not in the secondary vegetation.

The secondary vegetation had the highest number of umbrophile species individuals, such as Uroxys sp. nov., P. wagneri, C. euryscelis, C. cyanellus and A. perezvelai.

The ramon plantation had the highest species richness and the highest number of rare species, which suggests that establishment of 
these trees probably generated spaces favorable for dispersion of species that were historically distributed in the area, and whose original habitat has been modified (Estrada et al. 1998, Hernández et al. 2003). The rare species in this zone can be catalogued as "tourist species" (Moreno and Halffter 2001) that develop in surrounding habitats and then enter the ramon plantation. These species' populations may not be able to fully develop in this zone but they create transitory perch and feeding places, or use it as a feeding space, then disperse. According to Moreno and Halffter (2001), the tourist or transitory species phenomenon depends on an organism's mobility, as well spatial heterogeneity and the size relationships between zones.

This is relevant at Kampepem Ranch since the spatial heterogeneity created by the different land uses, zone size and the distance between zones probably favor the tourist species phenomenon. The collected species that can be called tourists include Uroxys sp. nov., P. wagneri, C. cyanellus, C. euryscelis and $S$. mexicanus, since all but the last had higher abundances in other areas.

The ramon plantation also contained species with broad distributions and ecological tolerance for fragmentation, such as $C$. indigaceus, C. leechi, Canthidium sp., P. perplexus and $O$. landolti. These species were more abundant in this zone and the pasture, suggesting connectivity between both zones.

The pasture had the lowest richness and diversity but the largest proportion of heliophile species, which are associated with disturbed areas and cattle.

The four dominant species in the three zones are almost the same (Uroxys sp. nov. and $C$. cyanellus replace Canthidium sp and a $C$. indigaceus in the secondary vegetation), which highlights their broad ecological tolerance. These species are especially important in the pasture because they quickly incorporate the dung into the soil, improving soil retention of volatile nitrogen and other components in the dung, accelerating decomposition of dung through digestion by adult and larval beetles, reducing access of infective stage intestinal parasites to cattle, reducing reproductive and growth habitat for flies that affect cattle and humans, and improving soil aeration, permeability and moisture retention (Bornemissza 1960).

The structural differences between the beetle assemblages of each zone illustrate the adaptation of the Scarabaeinae in the natural or succession vegetation zones and how this adaptation differs in a production system with a given land use. Though they did not have long-term data, Estrada et al. (1998) state that land use practices in the ranching landscape of Los Tuxtlas, Veracruz, have diverse effects on copronecrophile coleopter fauna. Apparently, the alternation of tree crops in the landscape reduces the physical and biological isolation of the beetle species that survive in the forest remnants. It creates a heterogeneous landscape in which the forest remnants, the man-made and natural corridors and the living fences between pastures generate a more benign environment for beetle survival than just open pastures.

The secondary vegetation seems to have the function of sheltering those species that are sensitive to deforestation or the opening of areas for cattle. It also probably functions as a genetic reserve for species that disperse to surrounding areas. The use of $B$. alicastrum trees is seen as an important element for the maintenance and dispersion of beetle species that degrade decomposing vegetal and animal matter on Kampepem Ranch, because almost the entire specific richness in the study area was found in this zone. Though the ramon plantation is an ecosystem modification, which is why it was evaluated, it has no apparent negative effect on the beetle community in the study area.

The pattern of generalist species at Kampepem Ranch did not coincide with that reported by Halffter et al. (1992) for Chiapas, in which the proportion of generalist species decreased notably outside areas with vegetal cover and the number of strictly coprophage species increased.

A significant difference in the proportion of umbrophile versus heliophile species was 
observed in the present study. Halffter and Arellano (2002) report that the opening of areas for cattle generates a decrease in the number of umbrophile and an increase in the number of heliophile species, as well as a shift from diurnal to nocturnal species. The present data do show a higher percentage of heliophile species in the pasture and a dominance of umbrophiles in the zones with tree cover, but no differences in beetle activity hours between zones.

One aspect observed here but not mentioned in the literature is the effect of pasture irrigation on beetle seasonality, an effect to be anticipated since the phenology of these coleopters in the Neotropics is linked to the rainy season (Halffter and Matthews 1966, Halffter and Edmonds 1982, Morón 2003b, and citations therein). To keep the grass alive in pasture production systems, irrigation is used to add moisture to the soil during the dry season, which probably affects beetle seasonality. Indeed, the present data show that beetle species in the pasture extended their activity to the beginning of the dry season, while abundances dropped in the other, unirrigated zones. This is especially marked in the species that had the highest peaks during the rainy season (i.e. C. leechi, O. landolti and Canthidium sp.) and that dropped in abundance as the dry season approached. These same species had an additional generation at the beginning of the dry season in the pasture, indicating that irrigation may favor the seasonal extension of species with broad ecological tolerance. This is not necessarily negative since these same species are those that make the greatest contribution to dung degradation in pastures (Bornemissza 1960).

According to Halffter (1991), soil is a key factor for understanding the Scarabaeinae because it is vital to their lifecycle. This is where their food is located, where all the immature stages of each species develop, where they spatially relocate food, and where their various nesting structures are built. Consequently, any study of the Scarabaeinae must include the different edaphological formations which they inhabit and their characteristics.
The ramon plantation and secondary vegetation had generally well-structured, shallow soils (21 to $38 \mathrm{~cm}$ deep) with high stoniness and rockiness percentages. The Scarabaeinae fauna in northern Yucatan apparently respond to these edaphic conditions, since it includes a larger proportion of roller species (10 rollers vs. 7 burrowers). Additionally, burrower species in the region nest at shallow depths (Halffter and Edmonds 1982), are mostly small in size, follow a type I nesting pattern (five species) and thus require very little edaphic depth since their nests have a simple gallery and are shallow (e.g. O. landolti, Canthidium sp., Uroxys sp. nov. and $A$. perezvelai).

Soils in the pasture had been mechanically modified, were deeper $(52 \mathrm{~cm})$ and had a lower stoniness percentage than the two arboreal zones. Nonetheless, the same species dominated as in the other two zones, though with fewer large species, which again highlights the importance of vegetal cover for species diversity. The pasture may have characteristics that are favorable to large species with more complex nesting patterns, but no such species were collected there. For example, the pasture would seem to be a good environment for $P$. wagneri due to the available deep soils and abundant food (ovine dung), but this species is umbrophile, which apparently limits its presence in this zone.

Despite the large quantity of dung in the pasture, its beetle community was not more diverse than in the other zones. This coincides with Halffter and Arellano (2002), who, in a comparison between areas with cattle and others with vegetation, found that the amount of dung in the pastures had no effect on species richness composition, but did affect the abundance of individuals using this resource. The lack of trees is clearly a determinant factor in richness composition, making the use of trees an important element in cattle systems (Estrada et al. 1998, Hernández et al. 2003).

The conventional methodology for establishing species feeding habits consists of naming a species' habits according to the percentage 
of that species caught in traps with different baits, be it dung, carrion or rotting fruit. The separation criterion generally requires that the capture be equal to or greater than $80 \%$ in any one of these three baits for a species to be classified as coprophile, necrophile or generalist (Halffter and Arellano 2002). This could not be done in the present study because the results did not match those in the literature, so the species' feeding habits were assigned based on bibliographic data. The feeding habits classification scheme for these species obviously requires further definition.

The implications of the trap collection method become clear when different trap types and sampling times are used. For example, Morón and Terrón (1984) state that the longer an NTP-80 is left in the field, the more effective collection is, whereas the longer conventional coprotraps are left out the lower the efficacy (Lobo 1992, Montes de Oca and Halffter 1995). Therefore, disparities in sampling results occur if just one trap type is used. Some studies using only one kind of necrotrap refer to some species as necrophages, while other studies classify them as coprophages or generalists. This is the case with Copris lugubris, cited by Deloya (1996) as a necrophile and by Kohlmann (2003) as a coprophile, without capture data from necrotraps. In the present study, C. lugubris was only collected from coprotraps, raising a number of questions: If this species is classified as a necrophile and necrotraps were placed, why did it not appear in them? Does this species feed only on carrion in the absence of dung? Does this mean that it could feed on another resource in the absence of carrion and dung? How specialized are its habits?

Low collection abundances lead to another problem, independent of the bait used in the traps. This is what occurred in the present study with $D$. lobipes, which was represented by four individuals in the necrotraps and five in the coprotraps. If the percentage of capture criterion for each bait type is used, D. lobipes would be classified here as a generalist feeder when in fact it is known to be a strict necrophage (Halffter 2003).
The above highlights the need to more precisely analyze neotropical Scarabaeinae feeding habits as far as resource use. Halffter and Matthews (1996) have acknowledged the variety of resources used by these insects for feeding and nesting and the difficulty of studying them in tropical forests without using baited traps.

This is further complicated by beetles' evolution towards coprophagous feeding. In a synthesis, Cambefort (1991) proposes that the main Scarabaeoidea feeding habit centered on saprophagia, principally of decomposing vegetal matter like bits of wood and dry leaves, and then evolved towards saprophagia of the softer, decomposed vegetal remains under dead trees. This led to a series of morphological adaptations to the mouth apparatus to use pasty, soft foods. Later came nesting behavior, which, based on evidence that some beetles groups made nests with decomposing organic matter and hummus, arose before coprophagy. When the terrestrial vertebrates began their evolutionary radiation during the Mesozoic, large depositions of dung occurred on the soil surface and the Scarabaeinae then had adaptations for handling pasty, ephemeral resources, their larvae developed in nests, and were adapted to being largely immobile and to depending on a single resource.

Halffter and Matthews (1966), however, also state that tropical forests are biomes in which new evolutionary radiations of Scarabaeinae have taken place. The lack of large mammal dung inside forests has generated regressive evolutionary processes like the loss in some Deltochilum of the ability to bury the ball-nest, as well as many trophic specializations.

This proposal suggests the possibility that the Scarabaeinae living in neotropical forests are opportunistic saprophages and have specialized habits for resources other than dung, because many of the species in the present study were observed using other resources. Examples from other authors include D. scabriusculum in the detritus of Atta genus ants (Halffter and Matthews 1966), D. gibbosum in different types of vertebrate and invertebrate carrion, 
different kinds of dung, chicken feathers, rotting melon, fermented malt and highly decomposed mushrooms (Morón 1979), and D. valgum as a predator of diplopods (Cano 1998 cited in Halffter 2003). Another example is $C$. indigaceus, which has been observed "rolling pieces of Opuntia (Cactaceae) cladods and fruit rinds; also the remains from Phyllophaga (Coleoptera: Melolonthidae) dead the night before, as well as being collected in necrotraps". In the present study this same species, along with C. leechi, was seen using the interior of dead diplopods, in the same manner as C. cyanellus (Favila 2001). Finally, Kohlmann (2003) classifies Canthidium sp. as a genus that feeds on dung, carrion, organic matter accumulated in the soil and even includes a granivorous species.

Because their feeding is not limited to humid vegetal detritus, Halffter and Matthews (1966) call the opportunistic saprophagia of the Scarabaeinae "secondary saprophagia". They also state that, with the exception of trophic specializations, it occurs in the absence of dung as many supposedly saprophagous species end up being coprophagous when dung is available. Overall, the evidence for feeding variability suggests that neotropical Scarabaeinae respond opportunistically to the availability of decomposing food resources.

This idea of feeding opportunism is further supported by Morón (1994), who reports that three Deltochilum species and Coprophanaeus sp. account for most of the necrophile biomass in the Northeast Mountains of the state of Hidalgo, Mexico. However, it is likely that the foundation of their food resources is humid vegetal waste, rather than dead animal material, since their population sizes could not be maintained on the dead animal material available in the area.

Trophic opportunism may also be determined by competition, since, if the importance of competition in beetle evolution is considered (see Cambefort and Hanski 1991, and citations therein), opportunistic saprophagia in the neotropical Scarabaeinae may be a strategy aimed at averting competition for food resources
(Krebs 1985). It is possible that the wide range of food used by the neotropical Scarabaeinae is one more strategy to avoid strong competition for what Cambefort and Hanski (1991) define as a scarce, ephemeral, spatially random and highly nutritious resource: dung.

\section{ACKNOWLEDGMENTS}

The authors thank David Magaña for allowing them to do fieldwork on Kampepem Ranch, and W. D. Edmonds, S. Ibañez-Bernal and Cuauhtémoc Deloya for helpful and constructive comments on this paper. The Consejo Nacional de Ciencia y Tecnología (CONACyT) provided partial support for this study through a postgraduate scholarship to E. Reyes (PIFOP$181249)$.

\section{RESUMEN}

Este estudio describe y compara la estructura de la comunidad de escarabajos copronecrófagos (Scarabaeinae) en tres zonas con diferente manejo al interior de un agroecosistema localizado en el norte de la Península de Yucatán. A lo largo de un año de muestreo sistemático se encontraron 17 especies de los géneros Canthon, Canthidium, Deltochilum, Pseudocanthon, Malagoniella, Onthophagus, Phanaeus, Copris, Uroxys, Sisyphus y Ateuchus. El área de vegetación secundaria tuvo la comunidad más diversa. En la plantación de Brosimum alicastrum (ramón) se encontró la mayor riqueza de especies. El potrero tuvo la menor riqueza y diversidad, pero en él se observó la mayor abundancia de Scarabaeinae en la estación seca. Las áreas con mayor cobertura arbórea tuvieron mayor diversidad y se encontró dominancia de las especies rodadoras sobre las cavadoras y de las especies de talla pequeña sobre las de tamaño grande. Nuestros datos muestran dos aspectos importantes: en el potrero (con riego) las especies de escarabajos extienden su actividad hasta el inicio de la época seca, mientras que las abundancias decaen en las áreas que no reciben riego; la posibilidad de que los Scarabaeinae neotropicales sean saprófagos oportunistas y tengan hábitos alimenticios especializados para disponer de otros recursos además del excremento. El ramonal beneficia al sistema completo pues provee de un espacio para la dispersión y permanencia de varias especies estenoecas a la cobertura vegetal.

Palabras clave: Scarabaeinae, fragmentación, Brosimum alicastrum, agroecosistemas, biodiversidad, Yucatán. 


\section{REFERENCES}

Anonymous. 1995. Carta de clima, vegetación y precipitación de Yucatán. México. Instituto Nacional de Estadística Geografía e Informática (INEGI), México DF.

Anonymous. 2002. Plan Estatal de Reforestación para el Edo. de Yucatán 2002-2007. Secretaría de Ecología (SECOL). Gobierno del Estado de Yucatán. Yucatán, México.

Anonymous. 2003. Species Accumulation functions (SpAcc2), Version Beta. Centro de Investigación en Matemáticas, A. C. (CIMAT). México.

Arellano, L. \& G. Halffter. 2003. Gamma diversity: derived from and determinant of Alpha diversity and Beta diversity. An analysis of three tropical landscapes. Acta Zool. Mex. (n. s.) 90: 27-76.

Baev, P. \& L. Penev. 1995. BIODIV: program for calculating biological diversity parameters, similarity, niche overlap and cluster analysis. PENSOFT, Sophia, Bulgary.

Bornemissza, G.F. 1960. Could dung eating insects improve our pastures? J. Aust. Inst. Agr. Science. 26: 54-56.

Cambefort, Y. 1991. From saprophagy to coprophagy, p. 22-35. In I. Hanski \& Y. Cambefort (eds.) Dung beetles ecology. Princeton. New Jersey, USA.

Cambefort, Y. \& I. Hanski. 1991. Dung beetle population biology, p. 36-50. In I. Hanski \& Y. Cambefort (eds.) Dung beetles ecology. Princeton. New Jersey, USA.

Carabias, J. 2003. Futuro de la conservación de la biodiversidad y sus ecosistemas: Una visión global, p. $227-$ 239. In P. Colunga \& A. Larqué (eds.) Naturaleza y Sociedad en el área Maya. Pasado, presente y futuro. CICY-AMC. Yucatán, México.

Chacón-León, M. \& C. Harvey. 2004. Contributions from live fences to the structure and connectivity of a fragmented landscape, Rio Frio, Costa Rica, p. 121-125. In L. 't. Mannetje, L. Ramirez, M. Ibrahim, C. Sandoval, N. Ojeda \& J. Ku (eds.) $2^{\text {nd }}$ International Symposium on Silvopastoral Systems. Mérida, Yucatán, México.

Colwell, R. K. 2004. EstimateS: statistical estimation of species richness and shared species from samples. Version 7.0.

Deloya, C. 1996. Los macro-coleópteros necrófilos de Tepoztlan, Morelos, México (Scarabaeidae, Trogidae, Silphidae). Folia Entomol. Mex. 97: 39-54.
Deloya, C. \& M.A. Morón. 1994. Coleópteros lamelicornios del distrito de Jojutla, Morelos, México (Melolonthidae, Scarabaeidae, Trogidae y Passalidae). Listados faunísticos de México (V). IBUNAM, México. $49 \mathrm{p}$

Edmonds, W.D. 1994. Revision of Phanaeus Macleay, a new world genus of Scarabaeinae dung beetles (Coleoptera: Scarabaeidae, Scarabaeinae). Contr. in Science (Nat. Hist. Mus. of Los Angeles County). 443: 1-105.

Edmonds, W.D. 2003. Tribu Phanaeini, p.58-65. In M.A. Morón (ed.) Atlas de los escarabajos de México Vol. 2: Scarabaeidae, Trogidae, Passalidae y Lucanidae. Argania. Barcelona, Spain.

Estrada, A., R. Coates-Estrada, A. Anzures \& P. Cammarano. 1998. Dung and carrion beetles in tropical rain forest fragments and agricultural habitats at Los Tuxtlas, México. Jour. Trop. Ecol. 14: 577-593.

Favila, M. 2001. Historia de vida y comportamiento de un escarabajo necrófago: Canthon cyanellus cyanellus LeConte (Coleoptera: Scarabaeinae). Folia Entomol. Mex. 40: 245-278.

Favila, M. \& G. Halffter. 1997. The use of indicator groups for measuring biodiversity as related to community structure and function. Acta Zool. Mex. (n. s.) 72: 1-25.

Flores, S. \& I. Espejel. 1994. Etnoflora yucatanense, fasc. 3, Tipos de vegetación de la Península de Yucatán. UADY. Yucatán, México. 135 p.

Gaston, K. 1996. What is biodiversity? p. 1-9. In K. Gaston (ed.) Biodiversity. Biology of numbers and difference. Blackwell. New York, New York, USA.

Halffter, G. 1991. Historical and ecological factors determining the geographical distribution of beetles (Coleoptera: Scarabaeidae: Scarabaeinae). Folia Entomol. Mex. 82: 195-238.

Halffter, G. 2003. Tribu Scarabaeini, p. 21-43. In M.A. Morón (ed.) Atlas de los escarabajos de México Vol. 2: Scarabaeidae, Trogidae, Passalidae y Lucanidae. Argania. Barcelona, Spain.

Halffter, G. \& A. Martínez. 1966. Revisión monográfica de los Canthonina americanos (Coleoptera: Scarabaeidae) (Parte I). Rev. Soc. Mex. Hist. Nat. 27: 89-177.

Halffter, G. \& E.G. Matthews. 1966. The natural history of dung beetles of the subfamily Scarabaeinae (Coleoptera, Scarabaeidae). Folia Entomol. Mex. 12-14: 1-312. 
Halffter, G. \& W. Edmonds. 1982. The nesting behavior of dung beetles (Scarabaeinae). An ecological and evolutive approach. INECOL, MAB-UNESCO. México, DF. $176 \mathrm{p}$.

Halffter, G. \& M. Favila. 1993. The Scarabaeinae (Insecta: Coleoptera) an animal group for analysing, inventorying and monitoring biodiversity in tropical rainforest and modified landscapes. Biol. Int. 27: 15-21.

Halffter, G. \& L. Arellano. 2002. Response of dung beetle diversity to human-induced changes in a tropical landscape. Biotropica 34: 144-154.

Halffter, G., M.E. Favila \& V. Halffter. 1992. A comparative study of the structure of the scarab guild in Mexican tropical rain forest and derived ecosystems. Folia Entomol. Mex. 84: 131-156.

Halffter, G., C. Moreno \& E. Pineda. 2001. Manual para la evaluación de la biodiversidad en Reservas de la Biosfera. M\&T-SEA. Vol. 2. Zaragoza, Spain. 80 p.

Hernández, B., J.M. Maes, C.A. Harvey, S. Vílchez, A Medina \& D. Sánchez. 2003. Abundancia y diversidad de escarabajos coprófagos y mariposas diurnas en un paisaje ganadero en el departamento de Rivas, Nicaragua. Agrofor. Amér. 10: 93-102.

Howden, H.F. \& O.P. Young. 1981. Panamanian Scarabaeinae: Taxonomy, distribution and habits (Coleoptera, Scarabaeidae). Contr. Am. Ent. Inst. 18: 204 pp.

Janzen, D. 1983. Seasonal change in abundance of large nocturnal dung beetles (Scarabaeidae) in a Costa Rican deciduous forest and adjacent horse pasture. Oikos 41: 274-283.

Jiménez-Osornio, J.J., A. Caballero, D. Quezada \& E. Bello-Baltazar. 2003. Estrategias tradicionales de apropiación de los recursos naturales, p. 95-106. In P. Colunga y A. Larqué (eds.) Naturaleza y Sociedad en el área Maya. Pasado, presente y futuro. CICY-AMC. Yucatán, México.

Kohlmann, B. 1984. Biosistemática de las especies norteamericanas del género Ateuchus (Coleoptera: Scarabaeidae: Scarabaeinae). Folia Entomol. Mex. 60: 3-81.

Kohlmann, B. 2000. New species and distribution records of Mesoamerican Ateuchus (Coleoptera: Scarabaeidae) Rev. Biol. Trop. 48: 233-244.

Kohlmann, B. 2003. Tribu Coprini, p. 45-58. In M.A. Morón (ed.) Atlas de los escarabajos de México Vol. 2: Scarabaeidae, Trogidae, Passalidae y Lucanidae. Argania. Barcelona, Spain
Krebs, C. 1985. Ecología. Estudio de la distribución y la abundancia. Harla. México. 753 p.

Lobo, J.M. 1992. El relevo microsucesional entre los Scarabaeoidea coprófagos (Col.). Misc. Zool. 16: 45-59.

Magurran, A. 1988. Ecological diversity and its measurement. Princeton, New Jersey, USA. 171 p.

Montes de Oca, E. \& G. Halffter. 1995. Daily and seasonal activities in a guild of the coprophagous, burrowing beetle (Coleoptera Scarabaeidae Scarabaeinae) in tropical grassland. Trop. Zool. 8: 159-180.

Moreno, C. 2001. Métodos para medir la biodiversidad. M\&T-SEA. Vol. 1. Zaragoza, Spain. 83 p.

Moreno, C. \& G. Halffter. 2000. Assessing the completeness of bat biodiversity inventories using species accumulation curves. Jour. of Appl. Ecol. 37: 149158

Moreno, C. \& G. Halffter. 2001. Spatial and temporal analysis of alfa, beta and gama diversities of bats in a fragmented landscape. Biod. Cons. 10: 367-382.

Morón, M.A. 1979. Fauna de coleópteros lamelicornios de la estación de Biología Tropical "Los Tuxtlas", Veracruz, UNAM, México. An. Inst. Biol. UNAM (ser. Zool.) 50: 375-454.

Morón, M.A. 1994. Fauna de Coleoptera: Lamellicornia en las montañas del noreste de Hidalgo, México. Acta Zool. Mex. (n. s.) 63: 7-59.

Morón, M.A. 2003a. Familia Scarabaeidae (sensu stricto), Diagnosis y diversidad, p.19-21. In M.A. Morón (ed.) Atlas de los escarabajos de México Vol. 2: Scarabaeidae, Trogidae, Passalidae y Lucanidae. Argania. Barcelona, Spain.

Morón, M.A. 2003b. Atlas de los escarabajos de México Vol. 2: Scarabaeidae, Trogidae, Passalidae y Lucanidae. Argania. Barcelona, Spain. 227 p.

Morón, M.A. \& R. Terrón. 1984. Distribución altitudinal de los insectos necrófilos en la Sierra Norte de Hidalgo, México. Acta Zool. Mex. (n.s.) 3: 1-47.

Morón, M.A. \& C. Deloya. 1991. Los coleópteros lamelicornios de la reserva de la biosfera "La Michilía”, Durango, México. Folia Entomol. Mex. 81: 209-283.

Morón, M.A., F.J. Villalobos \& C. Deloya. 1985. Fauna de coleópteros lamelicornios de Boca del Chajul, Chiapas, México. Folia Entomol. Mex. 66: 57-118. 
Morón, M.A., J. Caamal \& O. Canul. 1986. Análisis de la entomofauna necrófila del área Norte de la Reserva de Biosfera "Sian Ka'an" Quintana Roo, México. Folia Entomol. Mex. 69: 83-98.

Morón, M.A., C. Deloya \& L. Delgado. 1988. Fauna de coleópteros Melolonthidae, Scarabaeidae y Trogidae de la región de Chamela, Jalisco, México. Folia Entomol. Mex. 77: 313-378.

Munroe, T., B. Pettersson, M. Ibrahim \& C. Harvey. 2004. A biodiversity inventory and evaluation of forest and silvopastoral systems in Costa Rica, p. 117-120. In L. 't. Mannetje, L. Ramirez, M. Ibrahim, C. Sandoval, N. Ojeda \& J. Ku (eds.) $2^{\text {nd }}$ International Symposium on Silvopastoral Systems. Mérida, Yucatán, México.

Nair, P.K.R. 1997. Agroforestería. UACh. Edo. de México, México. 543 p.

Peck, S. \& A. Forsyth. 1982. Composition, structure and competitive behavior in a guild of Ecuadorian rain forest dung beetles (Coleoptera; Scarabaeidae). Can. J. Zool. 60: 1624-1634.

Peraza-Flores, L. 2004. Fauna de Scarabaeidae y Trogidae (Coleoptera: Scarabaeoidea) de dos comunidades vegetales de Yucatán. Tesis de Licenciatura. Instituto Tecnológico de Conkal, Yucatán, México. 98 p.

Rivera-Cervantes, L.E. \& G. Halffter. 1999. Monografía de las especies mexicanas de Canthon del subgénero
Glaphyrocanthon (Coleoptera: Scarabaeidae; Scarabaeinae). Acta Zool. Mex. (n. s.) 77: 23-150.

Soberón, J. \& J. Llorente. 1993. The use of species accumulation functions for the prediction of species richness. Cons. Biol. 7: 480-488.

Spector, S. \& A.B. Forsyth. 1998. Indicator taxa for biodiversity assessment in the vanishing tropics, p. 181-210. In G.M. Mace, A. Balamford \& J.R. Ginsberg (eds.) Conservation in a changing world. Cambridge, England.

Spector, S. \& S. Ayzama. 2003. Rapid turnover and edge effects in dung beetle assemblages (Scarabaeidae) at a Bolivian Neotropical Forest-Savanna ecotone. Biotropica 35: 394-404.

Vester, H. \& S. Calmé. 2003. Los ecosistemas terrestres de la península de Yucatán: Estado actual de los paisajes, vegetación, flora y fauna, p. 159-173. In P. Colunga \& A. Larqué (eds.) Naturaleza y Sociedad en el área Maya. Pasado, presente y futuro. CICY-AMC. Yucatán, México.

Wadsworth, F. 2000. Producción forestal para América tropical. Manual de agricultura \# 710-S. USDA-FS. San Juan, Puerto Rico. 603 p.

Zunino, M. 2003. Tribu Onthophagini, p.66-74. In M.A. Morón (ed.) Atlas de los escarabajos de México Vol. 2: Scarabaeidae, Trogidae, Passalidae y Lucanidae. Argania. Barcelona, Spain. 
